\title{
Female urinary incontinence and nursing care: a literature review
}

\section{Introduction}

As specialists in stoma therapy, we observed the need for special care for women with Urinary Incontinence (UI). Thus, we were interested in carrying out this study that has the object of research the nursing care for women with Urinary Incontinence (UI).

UI is considered a worldwide epidemiologically relevant public health problem. Urinary Incontinence is defined as: "the condition where there is involuntary loss of urine. Its specification is given by relevant factors such as: frequency, severity, precipitating factors of social impact, effects on hygiene and quality of life, measures to contain Loss, and if the individual, caregiver or partner seeks or desires help from health professionals for this cause ". ${ }^{1}$ Women are usually affected twice as often as men. ${ }^{2}$ This condition generates many effects in a woman's life, affecting her physical, social, mental well-being and significantly changes her quality of life.

The most common types of UTI are: stress (SUI) where there is involuntary loss of urine to the exertion, for example when coughing or sneezing; (UUI) where there is a sudden urge to urinate and there is no control over the detrusor muscle; And mixed (IUM) when the two forms are associated. ${ }^{3}$ Therefore, this study aims to analyze in scientific productions the nursing care aimed at female urinary incontinence and to identify in scientific productions the impacts caused by urinary incontinence in women's lives.

\section{Method}

A qualitative, bibliographical research was carried out in the form of an integrative review of the literature, whose purpose is to gather and summarize the scientific knowledge already produced on the subject investigated, that is, to search, evaluate and synthesize the available evidence to contribute with the development of knowledge on the subject. ${ }^{4}$

To guide the research, the following question was asked: What was produced in the literature on nursing care in female urinary incontinence? The research was carried out from December to January 2017 and the search in publications indexed in the following databases: Nursing Database (BDENF), and Latin American and Caribbean Literature in Health Sciences (LILACS) and in the Electronic library Scientific Electronic Library Online (SciELO). ${ }^{5}$ We chose these databases and library because they understand the literature published in Latin American and Caribbean countries, as well as Brazilian scientific-technical references in nursing and include periodicals from the health area. Female, Urinary Incontinence, Quality of life and Rehabilitation were used as descriptors. ${ }^{6}$

After the research question was raised, the following inclusion criteria were established: All articles published by nurses, available in full in national journals, indexed in the electronic databases, addressing nursing care to women with urinary incontinence and the impact on their Lives. Exclusion criteria defined the articles that are not related to the nursing area. Only 08 correspond to the research question, so they are part of the study in question. ${ }^{7}$
Volume 3 Issue 5 - 2017

\author{
Patricia Britto Ribeiro de Jesus \\ Nurse and teacher, Universidade do Estado do Rio de Janeiro, \\ Brazil
}

Correspondence: Patricia Britto Ribeiro de Jesus, Nurse and teacher, Universidade do Estado do Rio de Janeiro, Brazil,Tel +5521981044 710, Email patty_brj@hotmail.com

Received: May 29, 2017 | Published: August 30, 2017

\section{Results and discussion}

After analyzing the articles, two categories emerged: nursing care for women with urinary incontinence and the impact of urinary incontinence on women's lives. From then on, we proceed to the analysis of the selected articles, those that contribute to the achievement of the objectives proposed in the study.

\section{Nursing care for women with urinary incontinence}

The nurse as an important professional in the care of women with urinary incontinence should act as an educator, provide psychoemotional support and stimulate behavioral treatment. To this end, it is extremely important to plan the individualized nursing care directed to the needs of each incontinent patient, involving the family throughout the care process. ${ }^{8}$

Thus, nursing care stands out: ${ }^{8}$ assist the patient in the perception and adaptation of the incontinent being; Prevent losses associated with increased urinary frequency due to the use of diuretics in hypertensive patients; Early identification of UI risk factors; To stimulate self-care as the best way to cope with UI; To seek practical theoretical knowledge to deal with the incontinent patient; Encourage participation in support groups and exchange of experience; To foster trust and empathy in the nurse-patient relationship incontinent; Identify strategies to approach the incontinent patient; To guide change in lifestyle; Guide hygiene care and infection prevention; Stimulate the practice of physical exercise and reduction of body weight. ${ }^{9}$ Strengthen pelvic floor musculature; Stimulate use of physical exercise and body weight reduction; Strengthen pelvic floor musculature; Stimulate use of intermittent catheterization and maintain long-term bladder catheter care and use electro stimulation, biofeedback, and vaginal cones

\section{The Impact of Urinary Incontinence on Women's Lives}

Literature consulted shows that urinary incontinence contributes to the appearance of psychological, personal, sexual and social relationships, as well as physical and economic changes, negatively influencing women's quality of life. ${ }^{10}$ Urinary incontinence leads women to suffer social impact, through social isolation. Social isolation represents a frontier in which the individual does not engage fully, actively and egalitarian in society, with a social and psychological function that causes considerable impact, with the Loss 
of physiological autonomy, provoking feelings of shame, depression, anxiety, stress and everyday social restrictions. ${ }^{1,2}$

The financial impact is also cited as an important factor, since it prevents it from performing its functions with the same productivity. Fear of smelling urine among co-workers, frequent breaks to the bathroom, and spending on absorbents and other devices are some of the factors that justify the financial impact on the woman's life. ${ }^{7,11}$

\section{Conclusion}

In this study, it was found that incontinent women present similarities to the perception of urinary incontinence, since they find difficulties in dealing with it. The decision whether or not to take action on the problem is directly related to the experience and the particular conception of the causes and treatments available for urinary incontinence. ${ }^{12}$

The nurse has an important role with women with urinary incontinence and their caregivers/family members, being oriented to conduct the continence restructuration whenever possible, or facilitating conviviality with incontinence, regardless of the context in which the woman is inserted, and Taking into account physiological, psychological, social and environmental aspects. For this reason, it is of paramount importance that the nurse is committed to seeking the knowledge and skill to provide quality care to the woman with urinary incontinence.

\section{Acknowledgements}

None.

\section{Conflict of interest}

The author declares no conflict of interest.

\section{References}

1. Delarmelindo RCA, Parada CMGL, Rodrigues RAP, et al. Estratégias de enfrentamento da incontinência urinária por mulheres. Rev Esc Enferm USP. 2013;47(2):296-303.
2. Rodrigues RAP, Mendes MMR. Incontinência urinária em idosos: proposta para a conduta da enfermeira. Rev Latino-am enfermagem Ribeirão Preto. 1994;2(2):5-20.

3. Carvalho MP, Andrade FP. O impacto da incontinência urinária e seus fatores associados em idosas. Rev Bras Geriatr Gerontol Rio de Janeiro. 2014;17(4):721-730.

4. Botelho LLR, Cunha CCA, Macedo MO. método da revisão integrativa nos estudos organizacionais. Gestão e Sociedade Belo Horizonte. 2011;5(11):121-136.

5. Sacomori C, Nubia Berenice Negri, Fernando Luiz Cardoso. Incontinência urinária em mulheres que buscam exame preventivo de câncer de colo uterino: fatores sociodemográficos e comportamentais. Cad Saúde Pública Rio de Janeiro. 2013;29(6):1251-1259.

6. Caetano AS. Influência da atividade fisica na qualidade de vida e autoimagem de mulheres incontinentes. RevBrasMed Esporte. 2009;15(2).

7. Silva L, Lopes BHBM. Incontinência urinária em mulheres: razões da não procura por tratamento. RevEscEnferm USP. 2009;43(1):72-78.

8. Valença MP, Albuquerque AFLL, Rocha GMS, et al. Cuidados de enfermagem na incontinência urinária: um estudo de revisão integrativa. ESTIMA. 2016;14(1):43-49.

9. Leroy LS, Lopes MHBM, Shimo AKK. A incontinência urinária em mulheres e os aspectos raciais: uma revisão de literatura. Contexto Enfermagem. 2012;21(3):692-701.

10. Santos CRS, Santos VLCG. Epidemiologia das incontinências urinárias e anal combinadas. Acta Paul Enfermagem. 2009;22(3):328-330.

11. Lopes MHBM, Higa R. Restrições causadas pela incontinência urinária à vida da mulher. Revista Escola de Enfermagem USP. 2006;40(1):34-41.

12. Volkmer $\mathrm{C}$, Monticelli M, Reibnitz KS, et al. Incontinência Urinária feminina: revisão sistemática de estudos qualitativos. Ciência e Saúde coletiva. 2012;17(10):2703-2715. 